\title{
Long Jump Practice Lecture Towards Athletic Learning Results
}

\author{
Ishak Aziz $^{1 *}$ and Nelfia $\mathrm{Adi}^{2}$ \\ ${ }^{12}$ Dep. of Coaching, Faculty of Sport Science Padang State University, Padang, Indonesia \\ "Corresponding author. Email: ishakaziz@fik.unp.ac.id
}

\begin{abstract}
The purpose of this research is to acknowledge the how far the ability of the students in long jump practice lectures. When in learning result, especially in the long jump number is low, it will affect the overall results of athletic practice learning. The population of this study is all of the students who took the basic course in Athletics within 2 SKS.The sample were 27 students in section number 201720870022 with stratified sampling technique. Meanwhile, the data analysis that used is average difference test. Based on the results of the analysis conducted on data obtained in the field, an average pretest test of 3.999 was obtained with a total of 103.98. After being treated for four weeks with materials that have been prepared in accordance with the Semester Lecture Plan, an average of 3,993 was obtained in total of 103,81 .
\end{abstract}

Keywords: Long Jump, Learning, Athletic

\section{INTRODUCTION}

Nicholas P. Linthorne, Craig Baker, Montell M.M. Douglas, Gary A. Hill and Richard G. Webster (2011), Thema "Take-Off Forces And Impulses In The Long Jump". The optimum long jump take-off technique is a compromise between the conflicting desires of generating vertical impulse and minimising the horizontal braking impulse. We currently have no firm recommendation as to the usefulness of a force platform in improving an athlete's take-off technique.

Milan Matić1, Vladimir Mrdaković1, Nenad Janković1, Duško Ilić1, Đorđe Stefanović1, Saša Kostić (2012) "The standard multiple regression was used to calculate that our model (RUV, AL, KATD, AATD, LATD, TA, TOD) explained the variance L with $69 \%$. It was concluded that TOD, LATD and RUV statistically significantly explain the variance $\mathrm{L}$. To realize the maximum length of the jump, the jumpers should achieve the highest possible RUV and minimize the loss of the resulting take-off velocity with AL, the LATD should be about $63^{\circ}$, the KATD and TA should be increased, while the TOD should be shortened with the increase of RUV. It was found that $\mathrm{AL}$ does not correlate with RUV, but there is a statistically significant correlation of AL with TOD, which has a large impact on $\mathrm{L}$.

The process of change at the present time is so fast, sometimes, it can be uncontrolled and often unstable as a result of the rapid development of technology and information compared to the development of human life itself. This phenomenon makes in the development of competition increase fierce and sharp for superiority between one and another,between one country and another, therefore efforts to improve the quality of human resources are a top priority. This is the strategic position of Law No. 20 In 2003 national education functioned about developing and shaping the character of a nation with dignity in order to advance the life of the nation,aims to develop the potential of students to become human beings who believe and fear God Almighty, noble, healthy, knowledgeable, capable, creative, independent and become citizens of a democratic and responsible. Without an instrument that becomes a sign to limit the progress, it can be expected that this nation will be a nation that is far behind.

One of the instruments is education, Education is an important pillar in development in every country, if a country is regardless with education, it can be called as underdeveloped countries. Therefore, education plays a very important role for the progress of a country.Likewise, Indonesia is a developing country.To be more advanced, education must be a top priority

In order to implement it, government determines National Policies and national education standards to guarantee the quality of national education. The existence of a National Accreditation Board for Schools / Madrasah is an independent evaluation body that establishes program eligibility levels of primary and secondary education formal channels with reference to the National Education Standards. 
The number of complexity systems of human life increase significantly, the mastery of science and technology can not be negotiable for the continuity of a nation's civilization.For that in producing highly competitive human beings, college graduates must be equipped with adaptive abilities and can develop themselves in accordance with the changing needs of science and technology.Therefore, universities not only play a role as a teaching center,also as a center for carrying out research that can be implemented in the midst of society, in addition to doing community service.

In order to meet these stated goals, FIK has designed and defined the curriculum for the course.Among the sports practice courses that must be attended by all students include athletic sports courses, This practice course is a very complex natural human movement, that is a motion that demands a condition of strength,speed, endurance, flexibility and coordination as well as the ability of other elements.Movements in this branch are very important for developing innate abilities, and are useful for developing other sports.

To optimize lecture practices, various types of activities have been carried out.Each lecture will be carried out, then planning is prepared in advance based on the Semester Teaching Plan (RPS) of the course, the program is given by a team that routinely conducts discussions about teaching,increase student motivation.Likewise, the implementation of teaching evaluation, always together both in the implementation of practical tests and theory as well as in processing scores into values that always done together.

However, lately it can be seen the value of student practice, especially athletics courses in the long jump number is relatively very low. The relatively low value of the long jump practice gained by students, getting responses from various parties,some say that the measurement of the quality and quantity of tools is not sufficient to be used in learning or in the implementation of measurements. There are also those who say that the basic ability of students to attend lectures is very low. Inadequate and Inaccurate learning long jump method used by lecturers, the low interest of students in long jump lectures, the socioeconomic condition of students is less supportive ,the low willpower of students in completing long jump lectures with good results.Based on those phenomena stated earlier, it is necessary to conduct research to reveal the problems in the long jump lectures,so that this research can find a solution to overcome this problem. The results of this study are expected to be useful for lecturers, and for subsequent researchers, and for the development of science and especially for lecturers who teach practical
subjects.For lecturers, this research is a step forward in capacity building, lecturers especially cadre lecturers in developing and enhancing professional attitudes.For other researchers as reference material in conducting the same research or research more about the variables that affect long jump learning outcomes in athletics courses.

Learning outcomes known as learning outcomes are all skills and results achieved through the teaching and learning process in schools that are expressed by numbers or grades measured by tests of learning outcomes (Leslie: 1979).Bloom defines learning outcomes are: as a result of behavioral changes that include three domains, namely; cognitive domain, including;(1) knowledge, (2) understanding, (3) application, (4) analysis, (5) synthesis, and, (6) evaluation.The first two abilities, namely knowledge, understanding and application are usually classified as low cognitive levels.Meanwhile the other four abilities, namely analysis, synthesis and evaluation are often said to be high cognitive abilities.The affective domain includes (1) acceptance, (2) attention, (3) response, (4) adjustment, (5) appreciation, and (6) regulation. Psychomotor domains include; (1) perception, (2) Readiness, (3) guided responses, (4) mechanisms, (5) complex responses, (6) adjustments, and (7) creation (V: 1977).From the various classifications of learning outcomes stated above, in the national education system especially in formulating educational goals, the classification of learning outcomes from bloom is more often used.It means that those three domains are always the objects in seeing the achievement of educational goals.But of the three domains, the most valued by the lecturers in relation to the mastery of the skills of learning outcomes of motion is the psychomotor domain,without neglecting the cognitive and affective domains.

From the standpoint of education, learning means improvement in behavior and skills, or acquiring new behaviors and skills.Changes that occur in learning, especially changes in psychological functions are a condition and are the basis for improving behavior and skills. This includes changes in knowledge, interests and attention formed by psychological functions in the human person.

The learning outcomes obtained by students consist of four categories, namely: cognitive, psychomotor, emotional reactive and interactive (Romiszowski: 1981).Furthermore, the characteristics of a person's behavior obtained from learning outcomes are: (1) new behavior in the form of actual and potential abilities, (2) the new ability is valid for a relatively long time, and (3) the new ability is obtained through effort (Hergenhahn and Olson: 1993). 
Learning outcomes are internal abilities (Capability) which include: (1) intellectual skills, namely abilities that make a person competent on a subject so that he can classify, identify, demonstrate, and generalize a phenomenon.cognitive strategies, namely the ability of a person to be able to control his intellectual activity in overcoming new problems he faces.(3) verbal information, i.e. one's ability to use spoken and written language in expressing a problem.(4) motor skills, i.e. one's ability to coordinate muscle movements regularly and smoothly in a conscious state,(5) attitude, namely the tendency to accept and reject an object (Robert M: 1979).Student learning outcomes are influenced by two main factors, namely factors originating from students or internal factors which include;(1) physiological factors, including general physiological conditions and five sensory conditions, (2) psychological factors, including interests, intelligence, talents, motivation, and cognitive abilities.Factors originating from outside students or external factors include; (1) instrumental factors, namely in the form of curriculum, programs, facilities \& infrastructure, and teachers (teaching staff) ((Suryabroto: 2005).Both of these factors are very dominant towards one's progress in achieving learning outcomes.If only one aspect is not met, then the expected learning outcomes may not be achieved.

Based on the statements that have been described in the previous section, it can be concluded that learning activities are carried out through theory and practice.Likewise, learning is done at the Faculty of Sports Science.Learning is also done in theory and practice in a variety of subjects that must be attended by all students to complete their studies.

The implementation of the lecture process in general begins with the activities of students studying theories.After the theory is discussed, it is continued with the student activity in practicing the theories.Learning practice means someone in carrying out the learning process is more dominant psychomotor aspects. it is also mentioned that someone is doing motor activities.Motor learning is a constellation of knowledge about mastery, refinement, and strengthening of skills or techniques in sports in particular.Robb described a rearrangement of the basic patterns of movement that led to the change in behavior as a result of training.

Another definition states that motor learning outcomes are an increase in the expertise of a motoric skill caused by conditions of training or gained from experience, and not due to a process of maturation or temporary motivation and physiological fluctuations.Meanwhile, the characteristics of competencies that must be possessed by students after attending this practice lecture, including the emphasis set in each level / phase of learning.In accordance with syllabus which is the focus of practice in lectures there are three phases of motor learning, according to Kiram (1998) namely;1). The first level motor learning phase, namely the development and mastery of coordination roughly, 2). Second level motor learning phase, namely the development of mastery of fine coordination, and 3 ). The third level of motor learning phase is stabilizing coordination skills and forming skills. automation and transfer of skills to various situations and conditions.Motion skills are the ability to carry out movements effectively and efficiently, because movement skills are an expression of the quality of coordination and control over the parts of the body involved in motion.Based on the opinions expressed above, it can be concluded that motor learning outcomes are an attempt or human activity to change attitudes through the process of training in gaining skills and from being unable to do to being able to do. Therefore to be able to do it takes a learning process.

Every carrying out a practical learning process requires physical activity to do so or what is known as a psychomotor movement.In order for the learning process to run in accordance with the stated objectives, a method or pattern or strategy is needed.Surakhmad stated that the pattern starts from the pre-preparation of learning, followed by the learning process that must (a) the material becomes a process, (b) the existence of clear objectives will be achieved,(c), the existence of active (learners) experiencing, (d) the existence of teachers who are actively implementing (e) the existence of certain methods to achieve goals, and (f) the material of the interaction process takes place in situational bonds. The process of interaction occurs in learning needed a way or method to achieve the desired results.Rooijakers (1980) states that teaching methods must encourage successful growth and refinement of behavior patterns and foster the habit of developing skills in adjusting.

\section{RESEARCH METHOD}

This research is a quasi experiment, where prior to the start the pre-test is given treatment which aims to find out the basic abilities of students.Following after being given treatment again carried out post-test aimed at knowing improvement or the results of the learning process.The population is all students who take basic athletic practice courses. The sample used for this study were students in the 201720870022 section, amounting to 27 students.Analysis by the test of two mean differences. 


\section{RESULTS AND DISCUSSION}

Based on the results of the analysis conducted on data obtained in the field, an average pretest test of 3.999 was obtained with a total of 103.98. After being treated for four weeks with materials that have been prepared in accordance with the Semester Lecture Plan, an average of 3,993 was obtained and a total of 103 , 81.Therefore there is a decrease, even not significantly, that the difference between the pretest with the post-test 0,006 and the total number of 0,17 .

\section{CONCLUSIONS AND SUGGESTIONS}

\section{A. Suggestions}

It necessary increase the learning meeting time for long jump learning subject.It better SKS of Altetic lecture to increase from 2 SKS to 3 SKS.

\section{REFERENCES}

[1] Nicholas P. Linthorne, Craig Baker, Montell M.M. Douglas, Gary A. Hill and Richard G.

[2] Webster (2011). Veloso, Alves, Fernandes, Conceição, Vilas-Boas (eds.) Applied Biomechanics in Sports.

[4] Journal of Strength and Conditioning Research: October 2013 - Volume 27 - Issue 10 - p 2674 2684 doi: 10.1519 /JSC.0b013e31825fce65. Original Research

[5] Milan Matić1, Vladimir Mrdaković1, Nenad Janković1, Duško Ilić1, Đorđe
[6] Stefanović1, Saša Kostić2 (2012) ACTIVE LANDING AND TAKE-OFF KINEMATICS OF THE LONG JUMP UDC 796.012.36/431.2 1 Faculty of Sport and Physical Education, University of Belgrade, Serbia 2Secondary

[7] Technical School, Ub, Serbia.Series: Physical Education and Sport Vol. 10, No 3, 2012, pp. 243 $-256$.

[8] Leslie J. Briggs, Intructional Design Principles and Applications (New Jersey: Prentice- Hall, Inc, 1979),

[9] Yanuar Kiram, Belajar Motorik (Jakarta: Proyek Pembinaan Tenaga Kependidikan, 1996).

[10] Margaret D. Robb, The Dynamics of Motor Skill Aequitation (New Jersey: Prentice Hall Inc, 1972).

[11] B.E. Rahantoknam, Belajar Motorik (Jakarta: Proyek Peningkatan Pengembangan Perguruan Tinggi IKIP, 1986), p.10. Kiram, op. cit. p. 17.

[12] Siswanto Triatmojo, Peranan Keterampilan Gerak (http://www.yski.info/indexphp?opti on=comconten\&view=artcle\&id=144:pera n anketr ampilan-gerak\&catid=54:artikelguru\&itemid=139. (Diakses 22 Februari 2010).

[13] Winarno Surakhmad, Metode Pengajaran (Bandung: Jemmers, 1979), p.14. Ad. Rooijakkers, Mengajar Dengan Sukses (Jakarta: PT Gramedia. 1980), p. 7. 